\title{
Biochar and Compost Application of Livestock on The Growth and Results of Red Chili Plants
}

\author{
Ni Wayan Siska Damayanti, Yohanes Parlindungan Situmeang*, and Anak Agung Ngurah \\ Mayun Wirajaya
}

Agrotechnology Department, Faculty of Agriculture, Warmadewa University, Denpasar, Bali, Indonesia *ypsitumeang63@gmail.com

\begin{abstract}
This study aims to determine the effect of compost and biochar made from livestock manure and its interaction on the growth and yield of red chili plants. in former farmers' rice fields in Blahkiuh Village, Abiansemal District, Badung Regency, with an altitude of about 400-500 meters above sea level. This research activity took place from March to July 2020. The design used in this study was a factorial randomized block design (RBD) consisting of 2 factors, namely: chicken compost with 2 levels and 4 levels of biochar by testing the compost dose and the type of biochar with a dose of 15 tons ha ${ }^{-1}$. The interaction between the treatment of the effect of biochar dose $(B)$ and the dose of chicken compost $(K)$ had no significant effect on all observed variables. The biochar treatment had a significant to a very significant effect on most of the observed variables, except for the variable number of leaves, number of fruit, dry weight of fruit oven, dry weight of streak oven, which had no significant effect, while the chicken compost treatment had a very significant effect. real for all variables. Provision of chicken biochar type increased fruit fresh weight in the treatment of chicken biochar, which was $1387.49 \mathrm{~g}$ which increased by $18.13 \%$ compared to treatment without biochar, which was $1135.92 \mathrm{~g}$, while the fresh weight of fruit at compost dose chicken, namely $1455.13 \mathrm{~g}$, increased by $30.33 \%$ compared to the treatment without compost, namely $1013.74 \mathrm{~g}$
\end{abstract}

Keywords: Biochar; compost; and chili plants.

\section{Introduction}

Red chili (Capsicum annuum L.) is a plant that belongs to the Solanaceae plant family. Red chilies are a vegetable commodity that people cannot leave behind in their daily lives. The high need every day makes red chilies a strategic commodity. Red chilies contain nutrients needed by humans, such as vitamin $\mathrm{A}$, vitamin $\mathrm{C}$, carotene, iron, potassium, calcium, phosphorus, and also contain alkaloids such as capsaicin, flavenoid, and essential oils [1].

Based on data from [2] the production of red chili in Bali is 45.155 tons $^{-1}$, while in Badung Regency the production of red chili is 2.089 tons $^{-1}$ compared to other districts in Bali, Badung Regency including low red chili production. This encourages farmers to use organic fertilizers which have long-term effects that are good for the soil. The use of fertilizers in agriculture continues to increase in line with the increase in the level of intensification and the increasing diversity of fertilizers as an effort to increase agricultural output [3]. The use of biochar organic fertilizer and manure compost can act as a provider of plant nutrients and can improve the physical, chemical, and biological properties of the soil.

One of the organic fertilizers, namely manure, manure is a waste product from domestic animals such as chickens, goats, and cows which can be used to add nutrients, improve the physical and biological properties of the soil. The quality of manure greatly affects the response of plants. Chicken manure in general has advantages in the speed of nutrient absorption, a nutrient composition such as $\mathrm{N}, \mathrm{P}, \mathrm{K}$, and Ca compared to cow and goat manure [4]. The use of chicken manure serves to improve the physical and biological structure of the soil, increase the absorption 
of soil to water. The application of manure affects increasing aluminum and reducing soil $\mathrm{pH}$, this is because the organic matter from manure can neutralize the source of soil acidity. Manure will also contribute some nutrients to the soil which can function to support growth and development, such as N, P, dan K [5]. In addition to the use of organic fertilizers, namely by using composted chicken manure.

Compost is the result of fermentation or decomposition of organic materials such as plant residues, animal manure, or other organic waste [6]. Compost can be made from various kinds of organics, including chicken manure which contains high $\mathrm{N}, \mathrm{P}$, and $\mathrm{K}$ nutrients [7]. The decomposition of organic matter from plant and animal remains by decomposing microorganisms produces compost which functions as a soil amendment, improving soil physical, chemical, and biological properties [8].

According to [9] chicken compost or organic matter is the main source of soil nitrogen and plays a significant role in improving the physical, chemical, and biological properties of soil and the environment. In the soil, organic fertilizers will be broken down by organisms into hummus or soil organic matter. Organic matter functions as a "binder" of the primary soil grains into secondary grains in the formation of fixed aggregates. This situation has a major effect on porosity, storage, and water supply as well as aeration and soil temperature. Organic materials with high $\mathrm{C} / \mathrm{N}$ such as straw and husks have a greater effect on changes in soil physical properties than the organic matter that has been decomposed such as compost.

Chicken manure is important in providing macro and micronutrients such as $\mathrm{Zn}, \mathrm{Cu}, \mathrm{Mo}, \mathrm{Co}$, $\mathrm{Ca}, \mathrm{Mg}$, and $\mathrm{Si}$ increases the cation exchange capacity (CEC) of soil and can react with metal ions to form complex compounds so that metal ions that poison plants or inhibit the provision of nutrients such as $\mathrm{Al}, \mathrm{Fe}$, and $\mathrm{Mn}$ can be reduced. In chicken manure, the nutrient content is $\mathrm{N}$ $3.21 \%, \mathrm{P}_{2} \mathrm{O}_{5}, 3.21 \%, \mathrm{~K}_{2} \mathrm{O}, 1.57 \%$, Ca 1.57\%, Mg 1.44\%, Mn 250 ppm, and Zn 315 ppm [10].

Biochar is biological charcoal from incomplete combustion (pyrolysis), organic matter from agricultural products that can improve soil quality and can be used as an alternative for soil management [11]. Biochar has the potential to increase C-soil in a sustainable manner, water, and nutrient retention in the soil. Another benefit of biochar is that it can store carbon stably for thousands of years by immersing it in the soil. The advantage that can be obtained from the use of biochar is that it can function as a soil repairer, increase plant growth by supplying several useful nutrients and improve soil physical, chemical, and biological properties. The potential of biochar as a soil repairer, besides being able to improve soil physical, chemical, and biological properties, can also be the main source of material for the conservation of organic carbon in the soil. The addition of biochar to the soil increases the availability of $\mathrm{N}, \mathrm{P}, \mathrm{K} \mathrm{Ca}, \mathrm{K}, \mathrm{Mg}$, and soil CEC which in turn increases crop yields. The role of biochar in increasing plant productivity is influenced by the amount added [12].

The results of rice research [13] showed that soil given biochar 10 tonnes per ha could increase soil $\mathrm{pH}$ from 6.78 to 7.40 or increase to $9.14 \%$. The length of time that biochar is available in the soil can have a positive effect on the nutrients contained in the soil. The improvement of these properties also depends on the type of soil and the quality of the biochar used. Application of biochar into the soil increases the availability of the main cations, $\mathrm{P}$, and total $\mathrm{N}$ which affect crop production. The high availability of nutrients for plants is the result of increased nutrients directly from biochar, increased nutrient retention, and changes in soil microbial dynamics. Long-term benefits for nutrient availability are associated with higher organic carbon stabilization along with slower nutrient release than commonly used organic matter [11]. The highest fresh weight of chili fruit was obtained in the treatment of compost dosages of 30 tons per ha and biochar made from coconut shells [14]. The results of the research by [15] show that providing 15 tons per ha of 
compost and biochar from chicken manure gives the best results compared to compost and biochar from cow and goat manure. The purpose of this study was to determine the effect of compost and biochar made from livestock manure and its interaction on the growth and yield of red chilies.

\section{Material and Methods}

This research was conducted in former farmers' rice fields in Blahkiuh Village, Abiansemal District, Badung Regency, with an altitude of about 400-500 meters above sea level. This research activity took place from March to July 2020.

The materials used are the Pilar F1 variety of red chili seeds produced by Tunas Agro Seeds, compost, and biochar. While the materials used in the compost and biochar-making process are chicken, cow, and goat manure. The tools used in this research were: stationery, hoe, scratching, shovel, sickle, raffia rope, sprayer, cloth meter, digital scale, hammer, and sieve.

The design used in this study was a factorial randomized block design (RBD) consisting of 2 factors, one factor: chicken compost with 2 levels, namely: 15 ton $^{-1}$ chicken compost and without compost, the second factor: 4 levels of biochar by testing the type of biochar, cow, chicken, and goat biochar with a dose of 15 ton $\mathrm{ha}^{-1}$ thus a combination of 8 treatment combinations can be obtained: KoBo, KoBa, KoBs, KoBk, KaBo, KaBs, $\mathrm{KaBa}$, KaBk, and each treatment was repeated 3 times so that there are 24 experimental plots.

The research data were analyzed by using analysis of diversity to determine the effect of treatment on the measured variables. Meanwhile, to determine the real difference between treatments using the LSD test with a level of 5\%. To determine the closeness of the relationship between the observed variables, a correlation analysis was carried out. Furthermore, to determine the closeness of the relationship between the variables observed in the biochar treatment, a correlation analysis was carried out.

\section{Results and Discussion}

\subsection{Results}

Based on the results of statistical analysis, the effect of biochar type and compost dose on the observed variables during the study can be seen a significant effect in Table 1 .

Table 1.

Significance of the effect of the type of biochar (B) and the dose of compost (K) and its interaction $(\mathrm{BxK})$ on the growth and yield variables of chili plants

\begin{tabular}{lllll}
\hline No & Variable & $\mathrm{B}$ & $\mathrm{K}$ & $\mathrm{BxK}$ \\
\hline 1. & Maximum plant height & $*$ & $* *$ & $\mathrm{~ns}$ \\
2. & Maximum number of leaves & $\mathrm{ns}$ & $* *$ & $\mathrm{~ns}$ \\
3. & Rod diameter & $* *$ & $* *$ & $\mathrm{~ns}$ \\
4. & Fresh weight of fruit & $*$ & $* *$ & $\mathrm{~ns}$ \\
5. & Number of fruit & $\mathrm{ns}$ & $* *$ & $\mathrm{~ns}$ \\
6. & Stover fresh weight $(\mathrm{g})$ & $*$ & $* *$ & $\mathrm{~ns}$ \\
7. & Fruit oven-dry weight & $\mathrm{ns}$ & $* *$ & $\mathrm{~ns}$ \\
8. & Plant stover oven dry weight $(\mathrm{g})$ & $\mathrm{ns}$ & $* *$ & $\mathrm{~ns}$ \\
\hline
\end{tabular}

Note: $*=$ significant $(\mathrm{P}<0.05) .{ }^{* *}=$ very significant $(\mathrm{P}<0.01), \mathrm{ns}=$ no significant $(\mathrm{P} \geq 0.05)$ 
From Table 1, it shows that the interaction between the treatment of the effect of the type of biochar (B) and the dose of compost $(\mathrm{K})$ has no significant effect $(\mathrm{P} \geq 0.05)$ on all observed variables. The biochar treatment had a significant to a very significant effect on the variables of plant height, stem diameter, fresh weight of fruit, and fresh weight of stalks, while the variables of number of leaves, number of fruit, the oven-dry weight of fruit, and oven-dry weight of straits had no significant effect $(\mathrm{P} \geq 0.05)$. However, compost treatment has a very significant effect on all variables.

Table 2.

Average of observed variables due to the influence of biochar type (B) and compost dose (K)

\begin{tabular}{|c|c|c|c|c|c|c|c|c|}
\hline Treatment & \multicolumn{4}{|c|}{ Biochar (B) } & \multicolumn{3}{|c|}{ Compost (K) } & $\begin{array}{l}\text { LSD } \\
5 \%\end{array}$ \\
\hline Number of leaves (strands) & $101.29 \mathrm{a}$ & $112.92 \mathrm{a}$ & $107.00 \mathrm{a}$ & $113.79 \mathrm{a}$ & 18.86 & $97.71 \mathrm{~b}$ & $119.79 \mathrm{a}$ & 13.33 \\
\hline Rod diameter (mm) & $14.40 \mathrm{~b}$ & $16.05 \mathrm{a}$ & $15.98 \mathrm{a}$ & $15.98 \mathrm{a}$ & 0.96 & $14.67 \mathrm{~b}$ & $16.53 \mathrm{a}$ & 0.68 \\
\hline Number of fruit (fruit) & $79.25 \mathrm{~b}$ & $84.29 \mathrm{ab}$ & $88.00 \mathrm{ab}$ & $94.83 \mathrm{a}$ & 12.10 & $73.98 \mathrm{~b}$ & $99.21 \mathrm{a}$ & 8.56 \\
\hline Stover fresh weight $(\mathrm{g})$ & $254.94 \mathrm{~b}$ & $281.49 \mathrm{ab}$ & $315.17 \mathrm{a}$ & $309.75 \mathrm{a}$ & 43.67 & $254.07 \mathrm{~b}$ & $326.61 \mathrm{a}$ & 30.88 \\
\hline Fruit oven-dry weight (g) & $201.00 \mathrm{~b}$ & $202.08 \mathrm{~b}$ & $213.31 \mathrm{ab}$ & $246.43 \mathrm{a}$ & 41.66 & $182.28 \mathrm{~b}$ & $249.13 \mathrm{a}$ & 29.45 \\
\hline Plant stover oven-dry weight (g) & $69.77 \mathrm{~b}$ & $78.34 \mathrm{ab}$ & $88.35 \mathrm{a}$ & $87.24 \mathrm{a}$ & 14.98 & $66.64 \mathrm{~b}$ & $95.20 \mathrm{a}$ & 10.60 \\
\hline
\end{tabular}

Note: The average value followed by the same letter at the same treatment and row, means that it is not significantly different at the 5\% LSD test level.

\subsection{Discussion}

The results of this study indicate that the highest fresh weight of chili fruit was obtained in the treatment of chicken biochar $(\mathrm{Ba})$, namely $1387.49 \mathrm{~g}$ which increased by $18.13 \%$ compared to the treatment without biochar (B0), namely $1135.92 \mathrm{~g}$, while the fresh weight of the fruit at The dose of chicken compost (Ka), namely $1455.13 \mathrm{~g}$, increased by $30.33 \%$ compared to the treatment without compost (Ko), which was $1013.74 \mathrm{~g}$ (Table 2).

The high fresh weight of fruit per plant in the type of chicken biochar treatment $(\mathrm{Ba})$ and the dose of chicken compost (Ka) was supported by a significant correlation to the observed variables such as maximum plant height $\left(\mathrm{r}=0.89^{* *}\right)$, maximum number of leaves $\left(\mathrm{r}=0.71^{* *}\right)$, stem diameter $(\mathrm{r}=0.58 *)$, number of fruits $(\mathrm{r}=0.97 * *)$, fresh weight of stover $(\mathrm{r}=0.73 * *)$, oven dry weight of fruit $(\mathrm{r}=0.98 * *)$, and stover oven dry weight $(\mathrm{r}=0.74 * *)$ (Table 3).

Fresh weight of fruit in the treatment of chicken biochar $(\mathrm{Ba})$ was $1387.49 \mathrm{~g}$ which increased by $18.13 \%$ compared to the treatment without biochar (Bo) which was $1135.92 \mathrm{~g}$, the fresh weight of fruit in the treatment of cow biochar (Bs) was $1191,19 \mathrm{~g}$ which increased by $4.64 \%$ compared without biochar (Bo) $1135.92 \mathrm{~g}$, fruit fresh weight in the treatment of goat biochar (Bk) was $1223.13 \mathrm{~g}$ which increased by $7.16 \%$ compared to without biochar (Bo) $1135.92 \mathrm{~g}$, and the fresh weight of fruit at the dose of chicken compost (Ka), namely $1455.13 \mathrm{~g}$, increased by $30.33 \%$ compared to the treatment without compost (Ko) which was $1013.74 \mathrm{~g}$.

Based on Table 2 and Figure 1, the high fresh weight of fruit in this type of chicken biochar treatment is due to the ability of biochar to increase the main $\mathrm{P}$ cation and $\mathrm{N}$ concentration in the soil. Biochar is a soil repairer that can retain nutrients and water in the soil. Nutrient retention affects the growth of nutrients for plants, due to the nature of biochar which can improve soil aeration and drainage due to better soil porosity, decreased soil compaction, soil nutrient and water retention, and increased soil CEC. In line with the research of [16], giving biochar 10 tons ha ${ }^{-1}$ can increase the growth of maize plants. 
Table 3.

The correlation coefficient between variables ( $\mathrm{r}$ ) is due to the influence of the type of biochar

\begin{tabular}{lllllllll} 
& $\mathrm{X} 1$ & $\mathrm{X} 2$ & $\mathrm{X} 3$ & $\mathrm{X} 4$ & $\mathrm{X} 5$ & $\mathrm{X} 6$ & $\mathrm{X} 7$ & $\mathrm{X} 8$ \\
\hline $\mathrm{X} 1$ & 1 & & & & & & & \\
$\mathrm{X} 2$ & $0.87^{* *}$ & 1 & & & & & & \\
$\mathrm{X} 3$ & $0.89^{* *}$ & $0.86^{* *}$ & 1 & & & & & \\
$\mathrm{X} 4$ & $0.89^{* *}$ & $0.71^{* *}$ & $0.58^{*}$ & 1 & & & & \\
$\mathrm{X} 5$ & $0.96^{* *}$ & $0.74^{* *}$ & $0.72^{* *}$ & $0.97^{* *}$ & 1 & & & \\
$\mathrm{X} 6$ & $0.88^{* *}$ & $0.58^{*}$ & $0.82^{* *}$ & $0.73^{* *}$ & $0.87^{* *}$ & 1 & & \\
$\mathrm{X} 7$ & $0.80^{* *}$ & $0.57 \mathrm{~ns}$ & $0.43 \mathrm{~ns}$ & $0.98^{* *}$ & $0.93^{* *}$ & $0.66 \mathrm{~ns}$ & 1 & \\
$\mathrm{X} 8$ & $0.90^{* *}$ & $0.60^{*}$ & $0.83^{* *}$ & $0.74^{* *}$ & $0.88^{* *}$ & $1.00^{* *}$ & $0.68^{*}$ & 1 \\
\hline \multicolumn{7}{c}{$\mathrm{r}(0.05 ; 10 ; 1)=0.576$} & & $\mathrm{r}(0.01 ; 10 ; 1)=0.708$
\end{tabular}

$\begin{array}{ll}\mathrm{X} 1=\text { Plant height }(\mathrm{cm}) & \mathrm{X} 7=\text { Fruit oven dry weight }(\mathrm{g}) \\ \mathrm{X} 2=\text { Number of leaves }(\text { strands }) & \mathrm{X} 8=\text { Plant stover oven-dry weight }(\mathrm{g}) \\ \mathrm{X} 3=\text { Rod diameter }(\mathrm{mm}) & * \quad=\text { significant }(\mathrm{P}<0.05) \\ \mathrm{X} 4=\text { Fruit fresh weight }(\mathrm{g}) & * *=\text { very significant }(\mathrm{P}<0.01) \\ \mathrm{X} 5=\text { Number of fruit }(\text { fruit }) & \mathrm{ns} \quad=\text { no significant }(\mathrm{P} \geq 0.05) \\ \mathrm{X} 6=\text { Stover fresh weight }(\mathrm{g}) & \end{array}$

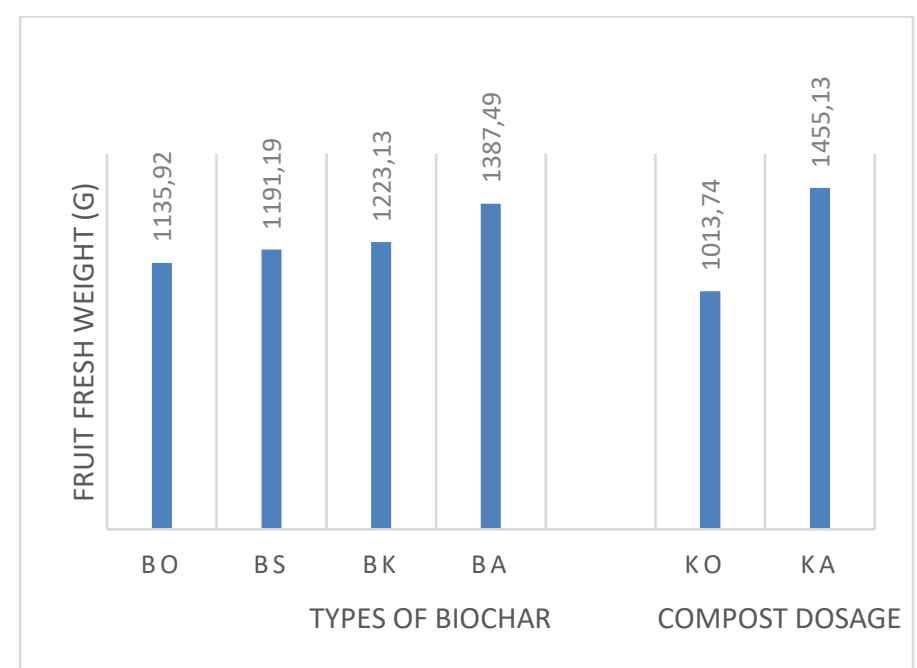

Figure 1. Relationship between types of biochar and compost dose with a fresh weight of fruit

The application of biochar can increase soil $\mathrm{pH}$, increase soil aggregate to increase soil moisture content, increase the ability of the soil to provide $\mathrm{Ca}, \mathrm{Mg}, \mathrm{P}$ and $\mathrm{K}$, increase soil microbial respiration, increase soil microbial biomass, increase cation exchange capacity, increase crop yield (20-120\%), and improve the quality of plant products [11].

Chicken compost gave better results compared to other treatments. This is because chicken compost in this treatment can meet the needs of plants such as $\mathrm{N}, \mathrm{P}, \mathrm{K}$, and several micronutrients in the form of $\mathrm{Fe}, \mathrm{Zn}$, and Mo [17] in producing fruit. Chicken compost can also contribute decomposer microorganisms to the soil so that the decomposition process of organic matter in the soil is better and can provide nutrients needed by plants for fruit formation. Microbial activity helps plants to absorb nutrients from the soil and produce compounds that can stimulate plant growth. Plants that are fertilized tend to be of better quality than those that are not fertilized, plants that are fertilized with harvested compost are more resilient, heavier, fresher, and tastier. The formation and filling of fruit are strongly influenced by nutrients $(\mathrm{N}, \mathrm{P}$, and $\mathrm{K})$ which will be used in the photosynthesis process, namely as a constituent of carbohydrates, fats, proteins, minerals, and vitamins which will be translocated to the storage of fruit. According to [18], fruit development is 
strongly influenced by the formation of auxins in the development of seeds and other parts of the fruit which function to supply food reserves to increase fruit development. The addition of organic matter has been shown to improve the soil physically, biologically, and chemically.

\section{Conclusion}

The interaction between the treatment of the effect of the type of biochar and the dose of compost did not have a significant effect on all observed variables, the biochar treatment had a significant to a very significant effect on the variables of plant height, stem diameter, fresh weight of fruit, and fresh weight of stalks, while the variable number of leaves, number fruit, oven-dry weight of fruit, and oven-dry weight of stunts were not significant, however, compost treatment had a very significant effect on all variables.

The highest fresh weight of chilies was obtained in the treatment of chicken biochar type, namely $1387.49 \mathrm{~g}$ which increased by $18.13 \%$ compared to the treatment without biochar which was $1135.92 \mathrm{~g}$. The fresh weight of fruit at the dose of chicken compost, namely $1455.13 \mathrm{~g}$, increased by $43.54 \%$ compared to the treatment without compost, which was $1013.74 \mathrm{~g}$.

\section{References}

[1] Devi, R.N. (2010). Budidaya Tanaman Cabai Merah. Tugas Akhir. Universitas Sebelas Maret. Surakarta.

[2] Badan Pusat Statistik (BPS) Provinsi Bali (2018). Produksi cabai merah. Katalog BPS : 1102001.51. http://www.bali.bps.go.id

[3] Warasfarm. (2013). Kelebihan Pupuk Kandang. Gadjah Mada University Press. Yogyakarta.

[4] Widowati. L.R., Widati. S., Jaenudin. U., Hartatik W. (2004). Pengaruh Kompos Pupuk Organik yang Diperkaya dengan Bahan Mineral dan Pupuk Hayati Terhadap Sifat-sifat Tanah, Serapan Hara dan Produksi Sayuran Organik. Laporan Proyek Penelitian Program Pengembangan Agribisnis. Balai Penelitian Tanah.

[5] Handayani, M. (2018). Pupuk dan Pemupukan. Fakultas Pertanian Universitas Andalas. Padang.

[6] Indriani, Y.H. (2008). Membuat kompos secara kilat. Penebar swadaya. Jakarta

[7] Atmojo, S.W (2003). Peranan bahan organik terhadap kesuburan tanah dan pengolahannya. Universitas Sebelas Maret Surakarta. Solo

[8] Setyorini, D. Saraswati, R, Anwar, E.K. (2008). Kompos. Pupuk organik dan pupuk hayati. Hal 11-37

[9] Widodo, (2008). Pupuk Organik dan Pupuk Hayati. Balai Besar Penelitian dan Pengembangan Sumberdaya Lahan Pertanian. Jawa Barat

[10] Wiryanta. W dan Bernardinus. T., (2002). Bertanam Cabai Pada Musim Hujan. Agromedia Pustaka. Jakarta.

[11] Gani, A., (2009). Biochar Penyelamat Lingkungan. Warta Penelitian dan Pengembangan Pertanian. Vol. 31, No. 6.

[12] Gani, A., (2010). Multiguna Arang Hayati Biochar. Sinar Tani Edisi 13-19 Oktober 2010.

[13] Nisa, K., (2010). Pengaruh Pemupukan NPK dan Biochar Terhadap Sifat Kimia Tanah, Serapan Hara dan Hasil Tanaman Padi Sawah. Thesis. Universitas Syiah Kuala. Banda Aceh.

[14] Amaral, H. D. D. R., Situmeang, Y. P., and Suarta, M. (2019). The effects of compost and biochar on the growth and yield of red chili plants. In Journal of Physics: Conference Series (Vol. 1402, No. 3, p. 033057). IOP Publishing.

[15] Situmeang. Y.P., Sudita, I. D. N., dan Suarta, M., (2019). Manure Utilization from Cows, Goats, and Chickens as Compost, Biochar, and Poschar in Increasing the Red Chili Yield. International Journal on Advanced Science, Engineering and Information Technology, 9(6), 2088-2095.

[16] Situmeang, Y. P., Adnyana, I. M., Subadiyasa, I. N. N., \& Merit, I. N. (2015). Effect of Dose Biochar Bamboo, Compost, and Phonska on Growth of Maize (Zea mays L.) in Dryland. International Journal on Advanced Science, Engineering and Information Technology, 5(6), 433-439.

[17] Sucahyono, D., Harsono, A. (2013) Keefektifan pupuk hayati dilahan asam, hasil penelitian tanaman kacang dan umbi. 
[18] Suprihartini, Y. (2013). Pengaruh pupuk kandang ayam terhadap pertumbuhan dan hasil tanaman cabai. Jurnal Produksi Tanaman, Hal 27-42. 